\title{
Editorial
}

Munishwar N Gupta

Much has happened since Rachel Carson wrote Silent Spring [1]. One no longer needs to define sustainability. However, its implication in the context of chemistry may be worth elaborating. Chemists are viewed as being largely responsible for using natural resources and (often) simultaneously hurting the environment. As Jenck et al. [2] pointed out, "Chemical industry represents a significant part of world trade and economic activity". So, one cannot suddenly stop the operation of chemical industries. The search for alternatives led the chemists to formulate 12 principles of green chemistry [3]; defining parameters like E factor, effective mass yield and mass intensity to judge how green a particular chemical process is [4]. A sustainable chemical process does not need an end of the pipe remediation step. So in that sense, it can be viewed as a subset of environmental chemistry which includes (and in fact focuses more on) waste treatment, detoxification and degradation of pollutants. Use of waste as a resource material to obtain value added products, however should be viewed as a part of Sustainable Chemistry. Whey was considered a waste product before biochemists turned it into a useful starting substance for producing sugars and bioethanol [5].

At present, the birth of green chemistry is viewed as "a paradigm shift from traditional concepts of process efficiency, that focus largely on chemical yield, to one that assigns economic value to eliminating waste at sources......." [4]. Perhaps, it needs to be appreciated that white biotechnology goes further and envisages that going "green" is profitable as well! [6]. Perhaps, chemists need to embrace that broader view. Just as Ayan Rand pronounced that selfishness is a virtue, we need to adopt sustainable chemistry for improving not merely our tomorrow but our today as well. I think we have now reached a point where that is possible. We are beginning to talk of "Green Engineering" [7]. In fact, as Winterton [8] observes, chemists and chemical engineers seem to be divided by a common discipline! This journal seeks to unify both by viewing a process to mean both reactions

Correspondence: appliedbiocat@yahoo.co.in

Department of Chemistry, Indian Institute of Technology Delhi, Hauz Khas, New Delhi 110016, India as well as unit operations which bring in the engineering aspects. So, the reference should be also made here to the 12 principles of engineering for Sustainable development, index of Sustainability and Ecoefficiency [7]. Sustainability is a complex concept. Many statements given in Carson's famous book have been debated. At one time, it was pointed out that replacing Styrofoam containers in restaurants by paperboard boxes does not necessarily help the environment [9]. Winterton has questioned the usefulness of E-factor [8]. More recent debate on biofuels worry about food versus fuel issues, and whether biodiesel is really a green fuel in view of life cycle studies also reflect this complexity. That however is the nature of science. All shades of scientific opinions should find a place in a good journal as a debate often does and should lead to further work. This journal does not aim to take sides. On all issues, it would publish any view if backed by valid data.

An interesting situation is in the context of water as a reaction medium. Carrying out organic reactions in water is now a well developed component of Green Chemistry. At the same time, process optimization aimed at minimization of consumption of fresh water is becoming increasingly important [10]. Few realize that one of the major applications of enzymes in edible oil extraction uses pectinase preparations for oil extraction from olives; the success of the technology is based upon the fact that enzyme based approaches use less water [5].

\section{About the current initiative}

This initiative, the journal Sustainable Chemical Processes is aimed at providing a seamless platform which would showcase the efforts in the area of sustainable chemistry at the entire range of levels - from test tube level to pilot plants. It is felt that the broad scope will bring in scientists from diverse disciplines. This should help cross fertilization of concepts and methods, and awareness of what is available in the tool box of scientists who work in the related sub-areas.

To ensure this, the journal has a very broad scope. All aspects of biocatalysis are covered (one has to weigh where use of enzymes is better than the use of chemical
(C) Chemistry Central

(c) 2013 Gupta; licensee Chemistry Central Ltd. This is an Open Access article distributed under the terms of the Creative Commons Attribution License (http://creativecommons.org/licenses/by/2.0), which permits unrestricted use, distribution, and reproduction in any medium, provided the original work is properly cited. 
catalysts or using an uncatalysed process. For example, organic solvents are not green media. However, use of enzymes in such media often is a better option and sometimes the only option!). Work on industrial ecology with a focus on chemistry/life cycle assessments etc. is welcome. Methods as far as they help in process development and improve its sustainability are not excluded. Manuscripts on environmental monitoring, control and analysis can be considered provided this aspect is integrated with an overall strategy for a sustainable process. The scope of the journal is given on the journal website. In case of a doubt, authors should feel free to enquire about the suitability of a manuscript by sending a very short abstract.

The open access model aims at a more inclusive dissemination of the results of the research. Quite often, the scarcity (of costly scientific tools) becomes the mother of innovation. So, allowing open access becomes a two way street. The scientists from rich nations are able to profit from such innovations happening at places which lacked costly scientific resources. These innovations, many times are possible because scientists working in less developed nations are able to access knowledge via open access journals.

As an author, sometimes I am disheartened about the irrationalities and oddities of the peer review system. Again, my own experience has been that the open access journals tend to have more proactive editors. In my opinion, an editor is not merely a post office. He/She is a catalyst which promotes and ensures a fair and efficient assessment of a manuscript. As an editor-in-chief, I aspire to play that role. As an author, like many fellow scientists, I have sometimes faced a situation when a journal returned the manuscript without reviewing, saying, send it to a more specialized journal (whatever that means). At one time, a famous journal which routinely publishes work on ionic liquids sent me a comment by a reviewer that ionic liquids are not green, so this paper does not describe green chemistry. On another occasion, I was told that use of enzymes affects environments! I would like to minimize such odd comments on the manuscripts submitted to this journal. No manuscript will be returned without review especially with a general and vague comment or a standard "form letter". For this, I am lucky to have a very vibrant editorial board consisting of active scientists from diverse disciplines.

I welcome suggestions from the scientific community on all aspects regarding this journal. I look forward to this journal publishing some good science and technology in the area of sustainable chemistry.

Received: 19 April 2013 Accepted: 19 April 2013

Published: 22 May 2013

References

1. Carson R: Silent Spring. London: Penguin Books Limited; 1965.
2. Jenck JF, Agterberg F, Droescher MJ: Products and processes for a sustainable chemical industry: a review of achievements and prospects. Green Chem 2004, 6:544-556.

3. Anastas PT, Williamson TC: Green Chemistry: Frontiers in Chemical Synthesis and Processes. Oxford: Oxford University Press; 1998.

4. Arends I, Sheldon R, Hanefeld U: Green Chemistry and Catalysis. Weinheim: Wiley-VCH: Verlag; 2007.

5. Godfrey T, West S: Industrial Enzymology. London: Macmillan Press Limited; 1996.

6. White Biotechnology: Gateway to a More Sustainable Future. http://www. bio-economy.net/reports/files/europabio_white_biotech_gateway_more_ sustainable_future.pdf.

7. García-Serna J, Pérez-Barrigón L, Cocero MJ: New trends for design towards sustainability in chemical engineering: Green engineering. Chem Eng J 2007, 133:7-30.

8. Winterton N: Chemists and chemical engineers: divided by a common discipline? Curr Opin Chem Eng 2012, 1:225-230.

9. Committee on Polymer Science and Engineering: National Research Council: Polymer Science and Engineering. Washington, D.C: The National Academies Press; 1994.

10. Klemeš JJ: Industrial water recycle/reuse. Curr Opin Chem Eng 2012, $1: 238-248$.

doi:10.1186/2043-7129-1-1

Cite this article as: Gupta: Editorial. Sustainable Chemical Processes 2013 $1: 1$.

Publish with ChemistryCentral and every
scientist can read your work free of charge
"Open access provides opportunities to our
colleagues in other parts of the globe, by allowing
anyone to view the content free of charge."
\[ \text { W. Jeffery Hurst, The Hershey Company. } \]
- available free of charge to the entire scientific community
- peer reviewed and published immediately upon acceptance
- cited in PubMed and archived on PubMed Central
- yours - you keep the copyright
Submit your manuscript here:
http://www.chemistrycentral.com/manuscript/

